\title{
The Value of Verse: Storytelling as Accounting in Froissart's Dit du florin
}

\section{Eliza Zingesser}

Et [Philozophie] dist, "Amis, se tu savoies

Que c'est grant cose de loenge

Et com prisie en est li enge,

Plus chier l'aroies a avoir

Qu'en tes coffres nul grant avoir."

And [Philosophy] said, "Friend, if you knew

What a great thing praise is

And how prized is its kind,

You would want it more dearly

Than any great sum in your coffers." (vv. 395-99)

Froissart, Le Joli Buisson de Jonece

The Dit du florin was written in Avignon in 1389, shortly after Froissart's visit to the castle of one of his patrons, Gaston Phébus, count of Foix and viscount of Béarn. In this 492-line dit, Froissart takes his last, misshapen coin as an interlocutor, conversing about the circumstances in which he lost most of the money paid to him by the count in compensation for his poetic services. The coin advises him to offset his loss by seeking further monetary rewards from four other patrons: Bureau de la Rivière, the count of Sancerre, the dauphin of Auvergne and the viscount of Acy (vv. 428-43), each of whom receives praise specifically with respect to his financial largesse. The text's most recent

I am grateful to $M L N$ 's anonymous reader, Sarah Kay, Ève Morisi and Alan Stahl for their helpful comments. 
editors, Kristen M. Figg and R. Barton Palmer, describe it as a "begging poem, whose circulation among the men it praises would be intended to elicit an appropriately generous response" (15). I think, however, that Michel Zink is rightly skeptical of Froissart's self-deprecatory posturing. Zink points out that while the author figure appears to be berating himself for his inability to hold onto his money, the coin presents another side of his career, reminding him (and readers) that he has written books that will immortalize him as a writer ("Le temps, c'est de l'argent" 1460).

The present article seeks to show that the façade of modesty and self-criticism of the Dit du florin is more superficial than has been realized. Couched in a frame in which Froissart appears to rebuke himself while praising his patrons is in fact a subtle demonstration of the power of the writer, who, through his stories (contes), does the real accounting (compte), determining the worth of various patrons, who may even be counts (comtes) such as Gaston Phébus, count of Foix. On several occasions (vv. 107-08, 276-77, 331-32, 381-82), Froissart invites readers to contemplate the link between these three homophonesnot always orthographically distinct in Middle French-suggesting that the writer wields more influence when it comes to the assessment of value than the wealthy patrons whose image he can manipulate at will. ${ }^{1}$ While Zink offers a reading of the coin in the Dit du florin as a symbol of time and memory, I will argue that it might be understood equally well as a double of the written text.

There are two salient parallels between currency and poetry, both of which Froissart seems to have been sensitive to. ${ }^{2}$ First, the value of coins, like the value of words, is not real or inherent but rather the result of contractual agreement. ${ }^{3}$ This was particularly true in the Middle Ages, when actual currency used as payment (monnaie de change) was distinguished from the money used for accounting and the determination of value ( monnaie de compte) ${ }^{4}$ Moreover, poetry, like

\footnotetext{
${ }^{1}$ Other rhyme pairs also suggest a relationship between financial transactions and poetry, such as that of langagier and engagier: "Je suis en vo commandement, / Soit dou vendre ou del engagier.' / Quant ensi l'oÿ langagier [...]" ("I am at your command, / either to sell or to use. / When I heard him speak in this way. ..") (vv. 176-78).

${ }^{2}$ The similarities between poetry and currency are explored at length in Shoaf's Dante, Chaucer, and the Currency of the Word.

${ }^{3}$ Even in the Middle Ages, when, unlike today, the value of a coin was related to the amount of precious metal it contained, the value of the coin depended on the availability of the metal.

${ }^{4}$ This distinction still holds today but the frequent fluctuations in value of different medieval currencies may have made it less abstract in the Middle Ages.
} 
currency, is a medium of exchange (involving ideas in one case and goods in the other) (Shoaf passim). Froissart suggests other parallels between accounting and the writer: currency circulates widely, and, at least within the context of the Dit du florin, is able to tell of its travels. Additionally, it is via written records that a patron's reputationwhich might be thought of as a kind of "value"-is established for posterity.

The association of coinage and artistic production probably makes its earliest appearance in medieval poetry in the figure of Nature's forge. In his deployment of this figure, Froissart follows in a line of illustrious writers including Macrobius, Bernard Silvestris, Alan of Lille, Heldris of Cornwall and Jean de Meun. ${ }^{5}$ All of these authors deploy the image of Nature at work in a forge-and sometimes the manufacture of coins-as a metaphor for procreation, with the coin normally being a symbol either for individual species or for individuals within a species. In Macrobius's Commentary, Nature's imposition of form is likened to the stamping of coins in the mint (Macrobius I.vi.63), while in the Romance of the Rose, Nature renews her "pieces" (v. 16015) with each new generation and makes various currencies on which Art models her own production. ${ }^{6}$ There is something paradoxical about the artificiality of Nature's production in the forge. ${ }^{7}$ Indeed, she consistently appears as a master craftsman, or artifex, even as early as Macrobius (I.vi.63). This paradox is one with which Jean de Meun plays in the Rose: in a passage that supposedly declares the supremacy of Nature and the inferiority of art, Jean undermines this position at every turn through rhetorical pirouettes such as equivocal rhyme ("forge / forge," vv. 16013-14; "oevre / oevre," wv. 16033-34; "paine / paine," v. 16039-40) and other highly unnatural (ostentatiously crafted) language, including an unusual density of rich and equivocal rhyme. Conversely, Art is to some degree more natural than Nature: she takes pleasure in depicting heraldic symbols in blue, yellow

\footnotetext{
${ }^{5}$ The image of Nature's forge has been traced by Suzanne Akbari ("Nature's Forge Recast”).

${ }^{6}$ Jean de Meun mentions "coins de diverses monnoies, / Dont ars faisoit ses examploires" ("coin dies of different currencies, / from which art made her exemplars") (vv. 16020-21). (A coin die is the object bearing the inverse image of the coin with which the coin is struck.)

${ }^{7}$ This paradox of the artificiality of Nature's production is neutralized by Alan of Lille, who, while presenting Nature as a writer, glosses writing as an act of natural reproduction, with particular focus on the encounter of phallic reed pens and slate tablets (De planctu Naturae, IV, Prose 2). Nature also describes the stylus as one of her "tools" in the Roman de la rose (Guillaume de Lorris and Jean de Meun 19510ff.).
} 
and green. To describe Art's preferred hues, Jean has recourse not to the highly conventional-and in this sense artificial—language of heraldry, but rather to the non-heraldic color names: "indes, jausnes ou verz" (v. 16046). ${ }^{8}$

Froissart as well seems to have been sensitive to the tension between art and nature in his appropriation of the image of Nature's forge, adopting this figure of natural reproduction to symbolize his own artistic output. In the prologue to Book IV of the Chroniques, he declares: "A la requeste [...] de [...] mon tres chier seigneur et maistre Guy de Châtillon, comte de Blois, [...] je, Jean Froissart, [...] me suis de nouvel resveilliés et entrés dedens ma forge, pour ouvrer et forgier en la haulte et noble matiere de laquelle du tamps passé je me suis ensonniez" ("Upon the request ... of . . . my very dear lord and master Guy de Châtillon, count of Blois, I, Jean Froissart, have once again awoken and entered my forge, to work and forge in the very lofty and noble material with which, in times past, I busied myself") (Chroniques III et IV 343-44). ${ }^{9}$ Although Froissart does not go so far as to describe his poetic output as a kind of coinage, readers familiar with the forge topos might well have made this inference.

The link on the horizon of this passage of the Chroniques between currency and poetry is paralleled in more explicit terms in the Prison amoureuse (ca. 1372). In this text, several maidens abscond with some of the texts Froissart has been composing, which he keeps in a pouch around his waist (the same place, significantly, that he might keep his money).$^{10}$ Instead of demanding a monetary ransom, they request payment with new compositions (La Prison amoureuse vv. 1105ff.) The poet returns home and writes a virelai, which he puts aside for fear that it will be stolen: "Le virelai mis a un les, / A fin qu'il ne me fust emblés; / Car tels prent tel cose alefois, / Qui lairoit bon viés gros tournois," "I put the virelai aside / So that it wouldn't be stolen; / For someone would immediately take such a thing / Who would leave a good old gros tournois") (La Prison amoureuse vv. 1244-47). His poetic compositions, it appears, are worth more than actual currency. In this

\footnotetext{
${ }^{8}$ Given this heraldic description of "armes" (v. 16046), one would expect to find the terms azur, or and sinople.

${ }^{9}$ Michel Zink notes the audacity of this image, by which Froissart suggests that his writing is comparable to the results of nature's work (Zink, "Froissart dans sa forge" 84).

${ }^{10} \mathrm{Jacqueline}$ Cerquiglini-Toulet also notes the association of forms of wealth and lyric composition in Froissart, particularly with respect to this passage of the Prison. Her approach, however, differs from mine in that she is primarily concerned to describe lyric composition as a kind of stockpiling (232-33).
} 
text, perhaps more transparently than in the Dit du florin, there is a clear valorization of the writer as "poete" and a treatment of the written text as a valuable object: it is alternately wrapped in silk, written in neat handwriting, and is often sent in ivory coffers. There is also a clear sense that writing is intended to preserve reputations (those of the writer and his patrons) for posterity and that this also contributes to its worth. Justice, for example, advises Rose that reputation-a domain over which writers have significant influence-is more valuable than actual wealth (La Prison amoureuse, vv. 2466-67). ${ }^{11}$

Froissart deepens this association between coins and writing in the Dit du florin. Near the beginning of this text, he describes money as a volatile object, which seems to pass from hand to hand and change shape despite the wishes of its owner. He asserts these characteristics using annominatio on the word change: "Argens trop volentiers se change / Pour ce ont leur droit nom li change" ("Money too willingly transforms itself [or: is exchanged]; for this reason exchange bureaux have the right name") (vv. 35-36). ${ }^{12}$ The deployment of paronomasia in these lines is the first hint in the text that currency is a figure for poetic language. While Froissart states that it is money that changes hands and shapes, the transformation of the word change from verb to noun mirrors precisely the property of mutation that is described. Froissart simultaneously asserts himself as an authority in the judgment of value, declaring the accuracy of the name "li change" (v. 36).

The poet further suggests the danger of the wide diffusion of the coin (or the text?), stating that money would make a good messenger because it passes through so many hands. One notes here the parallel between Froissart's extensive travels (described in vv. 168-69, 216-18) and this assertion of the wide circulation of currency. In the same vein, it becomes clear through Froissart's namedropping that he is, like money, "a toutes gens acointes" (v. 25). Like Froissart, the coin at the bottom of his purse is a polyglot who masters French, English and German (v. 153). ${ }^{13}$ Unfortunately, the author reminds us, money never returns to its owner (vv. 91-93). Are we to understand that poetic accounting is irreversible? The estimation of a patron, particularly

\footnotetext{
11 "Mieuls vault souffrete et bons renons / Que signourie et povres nons" ("Destitution and renown are worth more / than seigneury and disrepute") (La Prison amoureuse, vv. 2466-67).

${ }^{12}$ The fluctuation of currency was a particularly frequent phenomenon in the fourteenth century. Many rulers debased coins for profit, often to raise money for wars, usually by reducing the metal content of new coins (Spufford 289).

${ }^{13}$ Zink notes this parallel between the coin and Froissart ("Le temps, c'est de l'argent" 1457).
} 
once recorded in the exorbitantly expensive manuscripts in which Froissart's texts were compiled, can be rescinded but not effaced. As the coin suggests using equivocal rhyme, it is through his books that Froissart does his accounting: "Tout premiers vous avez fait livres / Qui ont couste bien .viic. livres, / Largent aves vous mis la bien" ("First of all you made books / That cost seven-hundred pounds; / You spent your money well there [or: you placed money well there]") (vv. 199-201). It is in his costly manuscripts that the poet keeps the books for posterity. ${ }^{14}$

Froissart invites us to view his works as repositories of value elsewhere in the Dit as well. After berating himself for his inability to hold onto his money for long, he asserts (in an apparent non sequitur) that he is not a builder (vv. 76-80). Among the physical spaces he announces he has not constructed (churches, clocks, caravels, ship galleys, houses, rooms and alleys) ${ }^{15}$ are several suspicious items, which reveal that there is perhaps a logical link between the money of which Froissart rapidly disposes and his missed calling as an architect. Indeed, by the time the reader encounters the Dit du florin on folio 213 of Bibliothèque Nationale de France's MS. fr. 830 (the production of which is thought to have been supervised by Froissart himself), ${ }^{16}$ he or she will already have stumbled-in the same order-upon a church (in the guise of the Temple d'onnour, which begins on folio 15v), a clock (in the form of the Orloge amoureus, folios $27 \mathrm{v}-36 \mathrm{v})$, and a ship and room in the Espinette amoureuse (f. 43ff., 2475ff., 2622ff.). ${ }^{17}$ These architectural metaphors may be an invitation to associate Froissart's prolific poetic output with expenditure, not just in the sense that his written production is costly because of the material and time involved, but also in that the finished poetic monument will retain its value for posterity.

Froissart further invites the reader to identify his poetry with accounting by framing the Dit as a mise en scène of the process of recordkeeping. He states that he had 2000 francs and will write the text to account for their whereabouts ("pour ravoir ent le compte," v. 107). ${ }^{18}$ This

\footnotetext{
${ }^{14}$ As one might expect, the coin of Froissart's text seems to be particularly sensitive to price and expenditure, while the poet figure is more interested in value. The coin reminds Froissart how much money he had (v. 211ff.) while the poet admits that he hasn't thought much about florins (v. 261).

15 "Je nen fais moustiers ne orloges / Dromons ne naves ne galees / Manoirs ne chambres ne alees" (vv. 78-80).

${ }^{16}$ See De Looze's introduction to La Prison amoureuse (xxiii).

${ }^{17} \mathrm{I}$ am grateful to Sarah Kay for drawing my attention to these scenes in the Espinette.

${ }^{18}$ See also the coin's reminder to Froissart that he wants an account: “. . . compte volés avoir" (v. 195).
} 
process of accounting is thus literally the material of the poem. Having beaten the lone coin that remains in his purse, he demands that it give an account of its activities ("Or ca il ten fault compte rendre," v. 118). The coin's compte will thereby generate another conte within the conte. Froissart's complaint that his other coins did not sing or speak ("ceulz [...] nont chante ne parle," v. 136) suggests another parallel between the coin and the writer: like Froissart, the coin can use language to do its accounting.

The way in which the poet employs this capacity for language is shown to be potentially beneficial (or harmful) to patrons. In a mise en scène of the process by which poetry can preserve (or subvert) a patron's image for posterity, Froissart describes the daily nocturnal journeys he made to Gaston Phébus's castle in order to read him excerpts from his romance, Méliador, which features Wenceslas of Brabant's lyric compositions. ${ }^{19}$ Having eagerly heard parts of the romance, Gaston tells the poet that it is a beautiful profession to create such writing ("c'est un beaus mestiers / Beaus maistres de faire telz choses," vv. 298-99).$^{20}$ In addition to describing Gaston's immediate reaction, Froissart describes the way in which he guides Gaston's reading of the text. He pronounces Wenceslas to be "bon" (v. 303) and mentions his fame ("dont on parla tant," v. 304). He continues to shape Gaston's image of the duke by drawing his attention to the lyric insertions, which preserve Wenceslas's image, like a kind of treasure chest: "Dedens ce rommanc sont encloses / Toutes les chancons que jadis / [ . . ] fit le bon duc braibant / Winceslaus" ("In this romance are enclosed / All of the songs that long ago / the good duke Wenceslas of Brabant made") (vv. 300-04). Just as Froissart draws the count of Foix's attention to the way in which Méliador has immortalized Wenceslas of Brabant, so the narrator of the Dit du florin makes it clear that a similar process could be deployed with respect to the count of Foix. His description of Gaston's castle as a place full of such astonishing light that even at night one would think it day, ${ }^{21}$ and his mention of

\footnotetext{
${ }^{19}$ These events are also described in Book III of the Chroniques. On the differing emphases of the two accounts, see Zink, "Le temps, c'est de l'argent" 1461.

${ }^{20}$ The vaguely chiastic structure of these lines is perhaps intended as an illustration of the beauty of the craft of writing.

21 "En la sale avoit tel lumiere / Ou en sa chambre a son souper / Que on y veoit ossi cler / Que nulle clarete poet estre. / Certes a paradys terrestre / La comparoie moult souvent" ("In the hall there was such light / or in his room at his supper / That one could see as clearly [there was as much light] / as any daylight could be. / Surely to terrestrial paradise / I often compared it," vv. 360-65). Froissart is only knowledgeable about the nocturnal lighting conditions of the count's castle because he has been
} 
the pure gold cup in which Gaston "generously" offers up the dregs of his wine to the poet ${ }^{22}$ lay the groundwork for a parallel between the count and the eponymous knight of Méliador, the "knight of the golden sun" ("chevalier au soleil d'or," v. 379). Unlike his assessment of the duke of Brabant, however, Froissart's impressions of the count of Foix are presented as subjective. Rather than describing the count of Foix's largesse as if it were a fact, he instead remarks that he found him to be generous and courtly ("[le] conte de fois / Que je trouvai larghe et courtois," vv. 311-12). The Count of Foix's poetic posterity thus seems more precarious than that of the illustrious duke.

Concluding his account of Gaston Phébus's encounter with Méliador, Froissart also notes, with a hint of disappointment, that the count failed to buy the manuscript from which he so obediently read each night (351ff.). Although he does not state outright that this act is not compatible with the largesse he has already attributed to the count (vv. 275-77, 331-33), he does suggest that he can change his tune. Immediately after he describes Gaston's refusal to buy his manuscript (vv. 387-88), he announces his decision to exchange his florins for francs. Like the units of currency he carries, his intention is not stable: "Je vinc la [Avignon] par un venredi / Et voloie, voir je te di, / Mettre tous ces florins au change. / Mes pourpos, qui se mue et change, / Se mua en moi sans sejour" "I came there [Avignon] on a Friday / and wanted, truly I tell you, to exchange all of these florins. / My intention (or: language), which moves and changes, / wavered in me without interruption") (vv. 391-95). We might read this implicit threat of a palinode, expressed through the metaphor of an exchange of currency, in parallel with Froissart's earlier description of himself as a craftsman ("ouvrier," v. 9) who is capable of shaping and reshaping coins from brute material without sending them to an actual mint, much like the writer shapes his stories from raw material: "Je l'aleue [l'argent] bien sans assai / Ne sans envoiier au billon" ("I put it into circulation without assaying it / And without sending it to the melting house/mint") (vv. 12-13). ${ }^{23}$ Likewise, the burlesque image of Froissart

\footnotetext{
repeatedly dragged from his bed and made to brave wind and rain to read to the count in the middle of the night (vv. 345-57).

22 "un vaissiel dor fin" ("a vessel of fine gold," v. 372).

${ }^{23}$ The Dictionnaire du Moyen Français gives the following definition for essai: "Opération qui consiste à vérifier la conformité de quelque chose à une norme, la qualité de quelque chose" ("An operation that consists of verifying the conformity of something to a norm, the quality of something"). In the Middle Ages, the assaying of coins involved melting them and separating their components to determine the percentage of each metal.
} 
beating the coin in his purse with the hilt of his sword frames him as the double of the monnayeur, who imprinted coins through hammering (vv. 123-24). The Count of Foix, it seems, is at risk of having his reputation deflated by Froissart the craftsman, much like the recently demonetized gros tournois casually mentioned at the beginning of the text (v. 65). ${ }^{24}$

The Dit concludes with Froissart's decision to keep his one remaining florin, and with a renouncement of all of the financial anxiety just described. Citing the wise words of Antoine of Beaujeu (vv. 485-86) and Gerard of Obies (v. 489) -in a final demonstration of the way in which his texts can enshrine those he favors-Froissart declares that silver marks will be worth no more than dog droppings on Judgment Day: "Autant vaudront au jugement / Estrong de chien que marq dargent" (vv. 491-92). One is reminded here both of the weighing of coins (one of the methods used to ascertain their value) and of the frequent depiction of the psychostasis (weighing of souls) in medieval scenes of the Last Judgment. This may be why Froissart refers specifically to marks, a unit of weight for silver and gold..$^{25}$ Although it remains unstated, the reader can infer that in the final reckoning, what will matter, rather than money, is one's record or history (often symbolized by an open book in depictions of the Last Judgment), and it is precisely this that the writer controls. While Froissart may not possess much actual monnaie de change, he insinuates that he retains power over the attribution of value, inflating and deflating his patrons' reputations at will.

Froissart witnessed a period of unprecedented monetary instability. Factors such as war (particularly the Hundred Years' War) and the Black Death certainly affected the French economy, but the frequent mutations in currency in fourteenth-century France had more to do with the royal power's attempts to increase its own resources (ostensibly to the benefit of the whole kingdom) than with "natural" causes (Fournial 115). To justify two mutations of currency in 1348 and another in 1349, Philip VI evoked ongoing war and the need to defend the French kingdom (Fournial 115). The situation worsened

\footnotetext{
${ }^{24}$ The minting of gros tournois was stopped by ordinance of Charles VI on March 11, 1385 and the currency was officially demonetized on September 26, 1388 (Fourrier, ed., Dits et débats 226).

${ }^{25}$ According to Fourrier, a mark represented eight ounces (Dits et débats 239). On the history of the mark as a unit of weight, see Fournial 26. Like the current pound, the mark was both a unit of weight and a unit of account in England and Germanic countries (my thanks to Alan Stahl for this observation).
} 
to the extent that, in 1355, Jean le Bon had to promise that "nous et nos successeurs ferons dorénavant perpétuellement bonne monnaie" ("we and our successors will henceforth perpetually make good currency") (Fournial 115). ${ }^{26}$ Such events led Nicole Oresme to protest, in his Traité des monnaies (1355 or 1356) that the sovereign does not own the currency that bears his stamp, and that he should not be allowed to change the proportion of gold and silver coins in circulation or to alter their weight (Oresme 54, 59, 63). ${ }^{27}$ Deriving monnaie from "moneo" (I inform), Oresme insists that the sovereign must be transparent in his dealings with currency, which also, he warns, bears the sovereign's image-an imprint that should act as a further guarantee of authenticity (Oresme 63, 64). Given these historical circumstances, Froissart's fascination with the determination of value is not surprising. Indeed, the exactly contemporary Songe du Vieil Pelerin by Philippe de Mézières is also constructed around the measure of value. Here the "besants" — coins—of mankind are to be assayed by Truth, Peace, Mercy and Justice through the use of hammering, magnets and fire. ${ }^{28}$ Froissart goes further than Philippe, however, in his suggestion that it is the writer who controls value. In his possession of this ability, he is akin both to the sovereign and to the counterfeiter-the traditional position of the artist in the forge. Indeed, Froissart's threat to his remaining coin that he will "disembowel" it so that it is "clipped" and "pared" suggests a literal process of devaluation: the clipping or paring of coins was both a common occurrence and a capital criminal offense in the Middle Ages. ${ }^{29}$

While Zink's reading of the coin as the "mémoire" and "conscience" of the poet has the merit of drawing attention to the way in which the coin can stand in for the poet, it is nevertheless one-sided: the florin is not just the poet's introspective memory. It is, additionally,

\footnotetext{
${ }^{26}$ This led many to attempt to store their wealth not in currency but in precious objects made of gold and silver that could be transformed into currency when necessary. This period is called one of thésaurisation by monetary historian Etienne Fournal, and one might well compare this to the aesthetics of thésaurisation described by Jacqueline Cerquiglini-Toulet.

${ }^{27}$ Oresme is thinking of situations in which the king first lowers the price of gold, then buys it with silver, then, once the price has gone up, resells his gold (or vice versa).

${ }^{28}$ I am grateful to Alan Stahl for directing me to the Songe.

29"Je t'esboulerai crapaudeaus / Bien voi que tu es uns hardeaus / Taillies, rongnies et rescopes" ("I will disembowel you, you little toad / For I see that you deserve the gallows / cut up, clipped and pared, vv. 127-9). One notes that Froissart has transposed the threat of execution from the coin clipper to the coin. Froissart's earlier (already quoted) suggestion that he puts coins into circulation without assaying them (v. 12) also frames him as a kind of counterfeiter.
} 
a powerful symbol of the way in which the poet constructs and controls cultural memory-i.e. the accounting of value for posterity. It is through writing, as Froissart notes in the opening of the Chroniques, that the memory of illustrious figures is transmitted from generation to generation: "Car, par les escriptures troeve on le memore des bons et des vaillans hommes de jadis . .." ("For through writing one finds the memory of the good and valiant men of the past") (Chroniques I et II 74). ${ }^{30}$ Likewise, Palmer and Figg's description of the Dit du florin as a "begging poem" fails to consider the way in which the balance of power is implicitly tipped away from Froissart's wealthy patrons and towards the writer. The actual currency these patrons give or withhold is ultimately worth less than the evaluation of them contained in his works.

\section{Princeton University}

\footnotetext{
${ }^{30} \mathrm{As}$ is clear from this article's epigraph, the association between the writer's praise and currency figures in the Joli Buisson as well. After extolling loenge as more valuable than currency, Philosophy explains that praise is the domain of writers. Without written trace of their heroic deeds, illustrious figures would be condemned to oblivion: "Que sceuist on qui fu Gauwins / Tristrans, Perchevaus et Yeuwains / Guirons, Galehaus, Lanscelos / Li rois Artus, et li rois Los / Se ce ne fuissent li registre / Qui yauls et leurs fes aministre?" ("What would one know of Gawain, / Tristan, Perceval and Yvain, / Guiron, Galahad, Lancelot, / King Arthur and King Lot, / If it were not for the record / that reveals them and their deeds?") (vv. 405-10). The association of writing with the preservation of loenge is discussed by Dembowski (35).
}

\section{WORKS CITED}

Akbari, Suzanne Conklin. "Nature's Forge Recast in the Roman de Silence." Literary Aspects of Courtly Culture. Ed. Donald Maddox and Sara Sturm-Maddox. Rochester, NY: D. S. Brewer, 1994. 39-46.

Alan of Lille. The Plaint of Nature [De planctu Naturae]. Trans. James J. Sheridan. Toronto: Pontifical Institute of Mediaeval Studies, 1980.

Cerquiglini-Toulet, Jacqueline. "Fullness and Emptiness: Shortages and Storehouses of Lyric Treasure in the Fourteenth and Fifteenth Centuries." Yale French Studies 80 (1991): 224-39.

Dembowski, Peter F. Jean Froissart and His Meliador: Context, Craft, and Sense. Lexington, Ky: French Forum, 1983.

DMF. "Dictionnaire du Moyen Français (1330-1500) ATILF-CNRS \& Nancy-Universitéhttp:/ / www.atilf.fr/dmf."

Fournial, Etienne. Histoire monétaire de l'Occident médiéval. Paris: F. Nathan, 1970.

Froissart, Jean. Chroniques: Livre I (première partie, 1325-1350) et Livre II: Rédaction du manuscrit de New York, Pierpont Morgan Library M.804. Ed. Peter F. Ainsworth and George T. Diller. Paris: Librairie Générale Française, 2001. 
Chroniques: Livres III (du Voyage en Béarn à la campagne de Gascogne) et Livre IV (années 1389-1400). Paris: Librairie Générale Française, 2004.

. "Dit dou flourin." Jean Froissart: An Anthology of Narrative E L Lyric Poetry. Ed. Kristen Mossler Figg and R. Barton Palmer. New York: Routledge, 2001.

La Prison amoureuse. Ed. Laurence De Looze. New York: Garland, 1994.

Froissart, Jean, and Guillaume de Machaut. Dits et débats. Ed. Anthime Fourrier. Geneva: Droz, 1979.

Guillaume de Lorris and Jean de Meun. Le Roman de la rose: édition d'après les manuscrits $B N$ 12786 et BN 378. Ed. Armand Strubel. Paris: Librairie Générale Française, 1992.

Macrobius, Ambrosius Theodosius. Commentary on the Dream of Scipio. Trans. William Harris Stahl. New York: Columbia UP, 1990.

Oresme, Nicole et al. Traité des monnaies et autres écrits monétaires du XIVe siècle. Ed. Claude Dupuy. Lyon: La Manufacture, 1989.

Shoaf, R. A. Dante, Chaucer, and the Currency of the Word: Money, Images, and Reference in Late Medieval Poetry. Norman, OK: Pilgrim Books, 1983.

Spufford, Peter. Money and Its Use in Medieval Europe. Cambridge [Cambridgeshire]: Cambridge UP, 1988.

Zink, Michel. "Froissart dans sa forge." Froissart dans sa forge. Actes du colloque réuni à Paris du 4 au 6 novembre 2004. Académie des inscriptions et belles-lettres \& Collège de France. Paris, 2006.

. "Le temps, c'est de l'argent. Remarques sur le Dit du florin de Jean Froissart." Et c'est la fin pour quoy nous sommes ensembles: Hommage à Jean Dufournet. Ed. JeanClaude Aubailly. Paris: Champion, 1993. 1455-1464. 